\title{
DISSEMINATION OF COPYRIGHT LAW IN DIGITAL PRODUCTS IN SEMARANG CITY
}

\author{
ANDRY SETIAWAN \\ Lecturer in Faculty of Law Universitas Negeri Semarang \\ Gedung K Kampus Sekaran Gunungpati Semarang \\ Email : andry_style@yahoo.co.id
}

\begin{abstract}
A creative work created by its creator based on his sense and intention which is supported by his creativity will become an intellectual work with a high economic value. Such creators are like book and song writers who have an ability and idea to produce a work that can be enjoyed by everyone. Based on the principle of justice, it is understood that to produce such work is not an easy task because it requires sacrifice. Therefore, the creator is entitled to economic benefits for his work. An intellectual work having a very high economic value is supposed to get adequate legal protection supported by a sense of justice as the reward of the creator's intellectual products. In addition to physical copyrighted work products, there are also digital products on which the creator owns a copyright. There are examples of digital products which follow the development of technology such as song files, e-books, software, etc. One of the problems that exists in the community is that the digital product becomes easier to be pirated or illegally downloaded through the internet. How is copyright protection in digital products as the embodiment of the creator's creative works. Copyright protection against creators and copyright holders pursuant to Act No. 28 of 2014 on Copyright. Article 1 number 1 and Article 24 paragraph (1) and (2). The creator or copyright holder has rights to be protected by the government, namely economic rights and moral rights. The existence of economic rights and moral rights is then someone's creative work will have its own values, so it is not easy to use his property for commercial purposes by the parties who are not responsible.
\end{abstract}

\section{Keywords: Copyright, Digital Product Protection}




\section{INTRODUCTION}

Since an intellectual property is part of property law, the creator is principally entitled absolute freedom to do anything with it according to his will and to give its desired contents in terms of its legal aspect. Being exclusive and absolute mean that these rights can be defended against anyone else. In other words, the right owner is able to file a lawsuit for any violation conducted by any irresponsible parties. In Indonesia, copyright is stipulated in the Copyright Act, i.e., the one which is currently applicable, Act No. 28 of 2014. It is defined in the Act that copyright is "an exclusive right for the creator or the recipient of the right to announce or multiply his creation or hence to grant permission without removing restrictions under applicable legislation" (Article 1 point 1).

Copyright in Indonesia also embodies the concept of "economic rights" and "moral rights". The economic right is the right to obtain the economic benefit of a creation. Therefore, the creator will gain an economic benefit from the results of his efforts in creating his work. The creator's economic rights can be obtained by multiplying and distributing his or her works both physically and in the form of digital products through the internet. The moral right which is inherent to the creators or workers of arts, recording, broadcast cannot be removed for any reason, even its copyright or the related rights have been transferred. For example, the implementation of moral rights is the inclusion of the creator's name in his creation, although the object's copyright has been sold for other's uses. The moral rights are set forth in the article 24-26 of Copyright Act. Consequently, there is a protection for the creator's economic rights and moral rights over his creations.

The current technological advancement, especially that in the information and communication technology in which the internet technology is globally increasing is inevitable. The internet poses either positive or negative impacts for the society. Its positive impact is that makes people easier get information more quickly and efficiently. Meanwhile, the negative impact is the rampant uses of copyrighted works like digital products such as songs or digital books (e-books), software etc. without permission. This brings about to negative impacts to the intellectual works creators such as songwriters and digital book writers. Such 
digital products, like other physical products, are also protected by a copyright. The low level of public knowledge about copyright protection makes them easily download the digital products regardless of their copyrights. This condition also makes them consider the acts of illegal download and usage are common things. People are already accustomed to using illegal digital products without feeling they have infringed the copyright and economic rights of the creators. In fact, there are already official digital or paid products over the internet which people can utilize when using a creator's work. This kind of usage will surely provide economic benefits for the creator as royalties.

Digital technology today has certainly made a new civilization in Indonesia even in other countries. Digital technology has established a new civilization that can change the social, economic, cultural, political, and security orders. There are a handful of people who will benefit from the presence of digital products that are generally preferred by people nowadays, for example, the creators of digital products, digital product marketers, etc.

\section{RESULTS AND DISCUSSIONS}

\section{The Review of Copyright on Digital Products}

In the current globalization era, we are experiencing a very rapid development, especially in the field of science and technology which effect on human activities. Media-based digital technology that becomes one of the indications of the advancement of information technology since there is the internet. The internet is no longer a taboo among the people and is essential for human life as it is considered a basic necessity in everyday life, as well as in the national and international businesses. The internet as a modern technology that is growing rapidly is inseparable from human life, even it has become a lifestyle (Riswandi, 2004: 133). These developments have created a new paradigm along with the widespread globalization whether in social, economic, or cultural fields which involves products which are produced on the basis of human intellectual capabilities such as creative works in the science, art and literature. 
Act No. 28 of 2014 on Copyrights in Article 1 paragraph 1 and Article 24 paragraphs (1) and (2), state that the creator or the copyright holder owns rights that must be protected by the government i.e. the economic and moral rights. The existence of the economic and the moral rights of someone's creative work will then have its own values. Therefore, his rights are not seized easily by someone who is not responsible. For example, a book author, with his ability and idea to produce a work that can be enjoyed by everyone, he is entitled to get legal protection for his creative works.

Creativity and ideas are expressed in a work of a person. The creator has inherent natural rights to control what he has created. Thus, he is acknowledged with every of his published works. The creative works circulating in society currently are commonly duplications of copyrighted works which are taken without the creator's knowledge. There has been a shift in the duplication forms of a copyrighted work like a song which is transferred into a tape or a compact disc, a book which is physically copied (printed). Nowadays, works like songs and books are transformed into digital products supported by technological developments. Digital products also known as e-products are non-physical products or usually electronic are usually traded online through the media of the internet. Digital products are stored, shipped and used in electronic format and the sale process is through a digital marketing. Digital products are intangible, impalpable and have no tradeable physical forms. Generally, these products are traded through the internet or online media whose selling, transactions, delivery processes are conducted electronically. The examples of creative works that have been digitized are songs in in $\mathrm{mp} 3$ format files and books in e-books formats.

Along with the development of an increasingly advancing internet world, digital products are now commonly traded and have their own customers. In addition, the development of digital products itself is closely linked with the efficiency and the practicality compared with that of physical products that requires special treatments such as storage space, packaging and delivery which are done conventionally. It is quite different from digital products that do not require physical space to store and whose delivery is usually conducted through 
digital download via the internet. The followings are some examples of other digital products: e-books (usually in PDF or Kindle formats), videos (usually in MP4 or FLV formats), software (usually in exe or air formats), MP3 Music (in the MP3 format), online tickets (in code or email formats), applications (android apps or iPhone apps). Here are some marketplaces that specifically sell digital products: Play Store, Apps Store, iTunes, Spotify and Joox.

If you are selling a digital product, you will benefit from its sales. However, these benefits are under piracy threats that occur to digital products. There are some examples of intellectual property in the digital products which are easily stolen, like music, designs, e-books, software, etc.

The article 40 paragraph (1) of Copyright Act states that there are works which are protected in Indonesia like those in the field of science, art, and literature, consisting of: (a) books, pamphlets, writings of published papers, and all other written works; (b) sermons, lectures, speeches, and other similar creations; (c) props made for the purposes of education and science; (d) songs and/ or music which is with or without lyrics; (e) dramas, musical dramas, dances, choreography, puppetry, and pantomime; (f) artworks such as paintings, drawings, carvings, calligraphy, sculptures, statues, or collages; (g) applied artworks; (h) architectural works; (i) maps; (j) batik artworks or other motifs; (k) photography works; (l) portraits; (m) cinematographic works; (n) translations, commentaries, data base, adaptations, arrangements, modifications and other transformation works; (o) translations, adaptations, arrangements, transformations, or modifications of traditional cultural expressions; ( $p$ ) compilations of creations or data, either in a format that is readable by a computer program or by other media; (q) compilations of traditional cultural expressions as long as they are the original works; (r) video games; and (s) computer programs.

The violations against the economic rights of authors like the activities of reprinting, reproduction, translation, adaptation, paraphrasing or transformation of the work, and the distribution of the creations or copies without the consent of the author shall be subject to imprisonment and fines. The perpetrator of this 
copyright infringement is a complaint offense until the creator files a lawsuit in order to get his right.

\section{Protecting Digital Products from Copyright Infringement}

The advancement of the current globalization era makes efforts of copyright protection, especially digital copyrights not easy tasks to do. The technological advancement is even exploited by irresponsible parties by committing piracy which surely will harm creators. Piracy in the digital world or other fields is principally an act of multiplying products without the permission from the people or parties who own the copyright.

It is very disturbing if digital products which are painstakingly created by the creators are so easily stolen or pirated by irresponsible people. If the creator sells his or her digital products without protecting them then it opens the opportunity widely for the pirates. Although the pirates may or may not take economic advantage from the digital product of the creator, they still harm the creator economically.

When facing new music, consumers like to spend time getting recommendation from music magazines, listening to music on the radio or in record store before making their purchase decision. The traditional way for record companies to provide information to consumers on the existence and the genre of new CDs and artists is to spend large costs on advertising and promotion. However, after the Napster experience, it has become clear that there is a cheaper way for consumers to obtain this information, by searching, downloading and testing digital music files made available through $\mathrm{P} 2 \mathrm{P}$ or other file-swapping technologies. This information transmission technology is rather different from traditional ads/promotions, as consumers not the firms are spending time and resources. In a sense, it is information-pull against information-push technologies. To sum up, digital copies of music files can be expected to have a strong informational role. ${ }^{1}$

1 Martin Peitz and Patrick Waelbroeck, Piracy of Digital Products: A Critical Review of the Economics Literature, September 2003, see at http://citeseerx.ist.psu.edu. 
The piracy of digital products cannot just be avoided. If the legal measures have been done, it's necessary that the creator also perform concrete actions to protect his digital products. There is a need for concrete steps other than registering the digital products by the creator, like: (1) performing a file security system which automatically "hides" the download page or creates a download key; (2) using a password on the download page of the digital product. It provides an automatic setting when the buyer has made payment and the creator sends a password to perform the downloading process.

Access controls and laws may yet enable the content industry to assert its control over audiences' eyes and ears, once it does get its encrypted content online. Or, the industry may need to return to the bargaining table and try to achieve yet another law to plug the perceived leak. There are noises being made in that direction already. ${ }^{2}$

\section{CONCLUSION}

The copyright regulation in Indonesia is found in the Act no. 28 of 2014 on Copyright. It is a protection for authors for his copyrighted works he created. The copyrighted works are not only physical works such as cassettes, compact disks, physical books but also technological developments can be mp3 song files, ebooks, software, etc.

The embodiment of the digital copyrighted works can be used in digital media such as the internet which is increasingly used by the community. Due to the low level of public knowledge about copyright and appreciation of copyrighted works, there are many illegal downloads of the digital products. Thus, it is hoped that the community will appreciate the creator's creative work more by understanding the Copyright Act and not committing illegal downloads of the digital products. The public should use a paid digital product so there is royalty for the creators as an economic benefit for his work.

Piracy in digital products will harm their creators economically and morally. In addition to legal protection, the creator must also take the necessary measures

2 See, e.g., Shane Ham and Robert D. Atkinson, Napster and Online Piracy: The Need to Revisit the Digital Millennium Copyright Act, Progressive Policy Institute Policy Report (May 2000). 
to prevent piracy. These steps are according to their respective digital product types, for example, by hiding digital products from the pirates and securing the download area. The other step is by using a password (password) or create a license key for each copy of a digital product.

\section{BIBLIOGRAPHY}

Bently, Lionel and Brad Sherman, 2009, Intellectual Property Law (Third Edition), New York: Oxford University Press Inc.

Eissman, Robert, 2004, WTO/ TRIPs Agreement and Access to Medicines: Appropriate Policy Responses, Malaysia: TWN

Hilman , Herlianti , and Ahdiar Romadoni, 2001, The Management and Protection Intellectual Property Assets, Jakarta: The British Council

Lindsey, Tim, et al, 2006, The Rights of Intellectual Property: An Introduction, Bandung: Alumni

Martin Peitz and Patrick Waelbroeck, Piracy of Digital Products: A Critical Review of the Economics Literature, September 2003, see at http://citeseerx.ist.psu.edu

Purba , Achmad Zen Umar, 2005, Post TRIPs Intellectual Property Rights, Bandung: Alumni

Shane Ham and Robert D. Atkinson, Napster and Online Piracy: The Need to Revisit the Digital Millennium Copyright Act, Progressive Policy Institute Policy Report (May 2000). 